\title{
UNA GALERÍA DE RETRATOS REALES: LOS SOBERANOS OMEYAS DE AL-ÁNDALUS (SIGLOS II/VIII-IV/X) EN LA CRONÍSTICA ÁRABE
}

\author{
A GALLERY OF ROYAL PORTRAITS: ANDALUSI UMAYYAD SOVEREIGNS \\ $\left(2^{T H}-4^{T H} / 8^{T H}-10^{T H}\right.$ CENTURIES) IN ARAB CHRONICLES
}

\author{
MANUELA MARÍN \\ Centro de Ciencias Humanas y Sociales, CSIC
}

Resumen: Se examina aquí la proyección pública y escrita de los soberanos omeyas de al-Ándalus a través de dos diferentes y complementarios testimonios, preservadoa en las crónicas árabes: en primer lugar, su aspecto físico tal como se describe en esas fuentes y, en segundo, las inscripciones de sus sellos. Ambas cuestiones se comparan con textos similares relativos a los Omeyas y Abbasíes de Oriente. Finalmente, se presentan conclusiones respecto al uso religioso y político de estas imágenes del poder.

Palabras clave: omeyas de al-Andalus; biografías y retratos personales; sellos.

\begin{abstract}
The public written projection of the Umayyad sovereigns of al-Andalus is examined throughout two different and complementary testimonies, preserved in Arab chronicles. First, their physical appearance as described in these sources, and secondly, the inscriptions in their seals. Both are compared with similar texts regarding Umayyad and Abbasid rulers in the Eastern parts of the Islamic Medieval realm. Religious and political uses of these images of power are finally offered.
\end{abstract}

Keywords: Umayyads from al-Andalus; biographies and personal portraits; seals.

\section{SUMARIO}

1. Introducción.- 2. El esquema biográfico del soberano.- 3. El retrato del príncipe: una iconografía textual.- 4. La inscripción del sello: un lema personal y dinástico.

\section{INTRODUCCIÓN}

Tal como ocurre en la tradición historiográfica del islam medieval, a la cual pertenece, la cronística andalusí se estructura a menudo en torno a las personalidades de los soberanos, cuyas biografías se convierten en el hilo conductor del relato histórico. Sin entrar a considerar la evolución de la historiografía islámica desde sus orígenes, sí conviene tener en cuenta su deriva hacia una recuperación "analística" de los hechos pasados y, en consecuencia, el establecimiento de una narrativa que, año tras año, se iba inscribiendo en el marco de una visión retrospectiva presidida por quien gobernaba la comunidad musulmana. Era inevitable, por tanto, que la biografía de los soberanos y el recuento analítico de su reinado se fundieran en un mismo texto ${ }^{1}$.

${ }^{1}$ Sobre historiografía árabe-islámica, véanse, entre otros, 'A. 'A. AL-DuRI, The Rise of Historical Writing among the Arabs, Princeton, 1983; Tarif KHALIDI, Arabic Historical Thought in the Classi- 
Aunque la literatura biográfica, especialmente en la forma de "diccionarios biográficos" dedicados a sabios, poetas, científicos, etc., haya conocido un desarrollo espectacular en el mundo islámico clásico ${ }^{2}$, no es a esta clase de biografías a las que me quiero referir aquí, sino a las dedicadas a los príncipes soberanos y que, por serlo, formaban parte de la narración histórica ${ }^{3}$. Las crónicas dedican una atención preferente a la personalidad de cada príncipe, puesto que ella ha de conformar el curso de los acontecimientos de su reinado e influir decisivamente en el devenir histórico de la comunidad. La biografía del monarca se convierte así en la historia del tiempo que le ha tocado vivir.

En ese contexto, la cronística árabe (tanto de autores andalusíes como de norteafricanos u orientales) sobre los omeyas de al-Ándalus permite reconstruir lo que puede considerarse como una auténtica "galería de retratos reales", que van desde su descripción física hasta el detalle de sus cualidades morales y sus actitudes personales, pasando por el ejercicio de su poder político y militar. Puede afirmarse que son los príncipes omeyas de al-Ándalus los individuos mejor conocidos de la sociedad a la que pertenecían: sus biografías describen no sólo su acción política y pública, sino también muchos aspectos de su vida privada y de sus actitudes personales.

Sin que ello sea excepcional en el contexto de la historiografía islámica medieval, cabe preguntarse hasta qué punto los cronistas se limitaron a hacer un "retrato del poder", recurriendo para ello a toda una serie de estereotipos historiográficos fácilmente reconocibles por sus potenciales lectores ${ }^{4} \mathrm{o}$ si fueron capaces de introducir, en ese marco, ciertas dosis de caracterización biográfica individualizada. Para responder a esta pregunta, me propongo examinar, a continuación, una crónica en concreto: alBayān al-mugrib fi ajbār al-Magrib del norteafricano Ibn 'I del siglo VIII/XIV ${ }^{5}$.

La elección de al-Bayān como hilo conductor de este trabajo se debe a varias razones. En primer lugar, y a pesar de la distancia temporal que separa a su autor de los hechos que describe, ya desde su primera edición (parcial) a mediados del siglo XIX ${ }^{6}$, el texto se convirtió en obra de referencia para la historia del occidente islámico por su carácter de compendio historiográfico; por lo que se refiere a al-Ándalus, se considera que se trata, en realidad, de un extracto de la magna obra de Ibn Hayyān, al-Muqtabis, conservado sólo de forma fragmentaria ${ }^{7}$. Por otro lado, constituye un relato coherente cuyo autor/compilador selecciona y ordena los materiales de que disponía, organizándolos para que el lector pueda obtener una visión general y compendiada de los hechos

cal Period, Cambridge, 1994; Albrecht Noth y Lawrence I. CONRAD, The Early Arabic Historical Tradition. A Source-Critical Study, Princeton, 1994, y Chase RoBInson, Islamic Historiography, Cambridge, 2003. Panoramas generales de la historiografía andalusí en María Jesús ViguerA, Cronistas de al-Andalus, en España, al-Andalus, Sefarad (F. Maíllo, ed.), Salamanca, 1998, pp. 85-98 y Manuela MARín, Ta'rīkh. Al-Andalus, en Encyclopaedia of Islam, $2^{\mathrm{a}}$ ed., s.v., Leiden, 2000. De la importante aportación a estos temas de Luis MoLINA señalo a título de ejemplo Los Ajbār Maŷmū ‘a y la historiografía árabe sobre el período omeya en al-Andalus, "Al-Qanțara”, X (1989), pp. 513-542.

${ }^{2}$ Fernando R. MEDIANO, El género biográfico árabe: apuntes teóricos, en Biografías y género biográfico en el Occidente islámico, (M. L. Ávila y M. Marín, eds.), Madrid, 1997, pp. 17-33, (EOBA, 8) y María Luisa ÁviLA, El género biográfico en al-Andalus, Ibidem, pp. 35-51.

${ }^{3}$ Michael CoOperson, Classical Arabic Biography. The Heirs of the Prophets in the Age of alMa'mūn, Cambridge, pp. 19-20.

${ }^{4}$ Jocelyne DAKHLIA, Le divan des rois. Le politique et le religieux dans l'islam, Paris, 1998, p. 12.

${ }^{5}$ Jacinto Bosch VILÀ, Ibn 'Idhārī, en Encyclopaedia of Islam, 2 a ed., s.v., Leiden, 1971.

${ }^{6}$ Debida a R. DozY, Leiden, 1848-51. La edición utilizada aquí es la de G. S. COLIN y E. LÉVIPROVENÇAL, Leiden, 1948-51, cuyo segundo volumen está dedicado a la historia de al-Ándalus hasta finales del califato omeya. Desde ahora se citará como Bayān, II.

${ }^{7}$ Mayte PENELAS, Introducción a La conquista de al-Andalus, Madrid, 2002, p. XXI. 
y sus protagonistas ${ }^{8}$. Otros textos cronísticos sobre la época omeya de al-Ándalus gozan de características similares, pero carecen de la continuidad de al-Bayān, bien por ocuparse de periodos más breves, como sucede con los anónimos Fath al-Andalus y Ajbār mâymu' 'a, o el Ta'rīj iftitāh al-Andalus de Ibn al-Qūtịya, bien por no haberse conservado en su integridad (al-Muqtabis). En todo caso, se tratará de situar las informaciones de Ibn 'I dārī en un contexto historiográfico más amplio, contrastando sus datos, siempre que sea posible, con los de otras crónicas y compilaciones.

\section{EL ESQUEMA BIOGRÁFICO DEL SOBERANO}

En la obra de Ibn 'Idāâī, como en la de algunos de sus predecesores en la historiografía islámica, el año de acceso al poder de un nuevo soberano se significa por la inclusión de lo que podríamos llamar, en términos actuales, una "ficha biográfica" . En ella se insertan una serie de datos considerados como imprescindibles para situar a cada príncipe en una línea genealógica que legitima su nombramiento y lo inserta en un contexto familiar -en principio, por tanto, privado- con repercursiones que van mucho más allá, puesto que la reproducción dinástica depende de unas estrategias matrimoniales y de parentesco que adquieren por ello un relieve fundamentalmente público $^{10}$.

Esta "ficha biográfica" se compone de una serie de entradas en las que se hace constar cuál es su inserción en la línea de sus antepasados varones (nasab), el nombre y origen de su madre y su propia kunya (el apelativo que vincula, en principio, a una persona con el nombre de su primogénito varón). Junto a estos datos genealógicos se mencionan el lugar y fecha de nacimiento, fecha de muerte, lugar de enterramiento, edad a la fecha de muerte, duración de su reinado y fecha de su proclamación ${ }^{11}$. Se añade a ello, bien dentro de este esquema, bien más adelante, información sobre el número y nombre de los hijos, tanto hombres como mujeres. La única excepción, a este respecto, es la biografía de Hišām II, del cual tampoco se ofrecen otros datos fundamentales: fecha y lugar de muerte, enterramiento, edad a su muerte... ${ }^{12}$ Como es bien sabido, todo ello está cubierto por un espeso velo histórico que propició la aparición de impostores que pretendían ser el propio Hišām II; lo que interesa aquí es subrayar cómo su ficha biográfica deja en blanco una serie de entradas que impiden asegurar la continuidad dinástica hasta entonces bien establecida. La falta de hijos de Hišām II deja en suspenso la continuidad de los omeyas (aunque ésta se fuera haciendo de manera irregular y espasmódica hasta llegar a la completa eliminación del poder omeya cordobés ${ }^{13}$ ).

${ }^{8}$ De un carácter similar es la compilación Dikr bilād al-Andalus, editada y traducida por L. MoLINA, Madrid, 1983, que la sitúa en la segunda mitad del siglo XIV o en el siglo XV.

${ }^{9}$ Esta ficha, o textos parecidos, puede encontrarse también como colofón al relato analístico de los diferentes reinados.

${ }^{10}$ Sobre las fronteras entre el ámbito de lo privado y lo público en el mundo medieval, v. M. ERLER y M. KowAleSKI (eds.), Women and Power in the Middle Ages, Athens (Ga.), 1988, pp. 2-4.

${ }^{11}$ Así es la ficha biográfica del primero de los omeyas, 'Abd al-Raḥmān al-Dājil, en Bayān, II, 47. Con ligeras diferencias, el mismo esquema se aplica a todos sus descendientes soberanos.

${ }^{12}$ Bayān, II, p. 253.

${ }^{13}$ Peter SCALES, The Fall of the Caliphate of Córdoba. Berbers and Andalusis in Conflict, Leiden, 1994, p. 115, señala que las informaciones de Ibn Hazm en su Ŷamhara apuntan hacia una "crisis demográfica" de los marwāníes, muchas de cuyas familias se extinguen progresivamente; pero concluye (p. 131) que no se trata de una estricta desaparición física, sino de la pérdida de memoria genealógica por parte de los descendientes de los omeyas. Véase ahora Eduardo MANZANO MoRENO, 
Junto a estos datos, la "ficha biográfica" de cada soberano incluye menciones a quienes podrían englobarse en el "entorno del poder", es decir, los que ejercían los cargos más importantes de la administración, nombrados para ello por el príncipe: visires, chambelanes, secretarios de cancillería, jueces, jefes de policía y generales. Debe hacerse notar que en el texto de Ibn 'Idārī, las dos últimas categorías no siempre se mencionan, mientras que todas las demás aparecen regularmente. No constan, por otra parte, dentro de ese retrato de la administración soberana, los nombres de los gobernadores de las provincias, aunque tanto ellos como los jefes del ejército aparezcan luego en la narración analística. De forma que, en la constelación de breves datos que conforman la "ficha biográfica" de cada príncipe, prima el ámbito de la administración del palacio - la sede misma del poder- y de la justicia, lo que quizá pueda explicarse por razones historiográficas (quienes escriben las crónicas proceden de los estamentos letrados de la sociedad, más interesados en preservar la memoria de visires, chambelanes, jueces y secretarios, que la de los jefes de policía, gobernadores o mandos militares), pero que también cabe interpretar como intento de proyectar una imagen de un poder soberano dotado de un entorno propio, definido por criterios de creación y reproducción de élites cultivadas y cortesanas.

Tras la "ficha biográfica", la crónica de Ibn 'Idārī consta de otros dos grandes apartados: el relato analístico de cada reinado y, tras la mención de la fecha y circunstancias de la muerte del soberano, una parte consagrada a sus "noticias" (ajbār) y "hechos señalados" (siyar). Es allí donde puede encontrarse, a través de una serie de relatos ejemplarizantes, anécdotas y breves textos caracteriológicos, un retrato que sería anacrónico calificar de psicológico, pero que contiene datos suficientes para establecer la suma, a veces contradictoria, de las cualidades personales de cada soberano, una especie, por tanto, de etopeya.

El perfil biográfico así obtenido es notablemente variado y se compone de una serie compleja de elementos que han de ponerse en relación entre sí para obtener un retrato final de cierta verosimilitud. Juegan en ello su parte los estereotipos adjudicados a los monarcas, que inevitablemente aparecen y se repiten de biografía en biografía $^{14}$, pero un examen cuidadoso de los textos muestra hasta qué punto la cronística incorpora variables no siempre reducibles a la categoría de tópico historiográfico. En lo que sigue, sin embargo, voy a limitarme a considerar dos de las "entradas" de la "ficha biográfica" de los príncipes omeyas de al-Ándalus que, hasta donde yo sé, no han sido objeto hasta ahora de atención específica, siendo así que describen, por un lado, el aspecto físico de los soberanos y, por otro, una muy señalada formulación de su poder ${ }^{15}$.

\section{EL RETRATO DEL PRÍNCIPE: UNA ICONOGRAFÍA TEXTUAL}

"Su aspecto" (șifatu-hu): así se inicia, en la "ficha biográfica", el detalle de las características físicas del soberano. Aunque en la etapa formativa de las artes islámicas no fueran desconocidas, ni mucho menos, las representaciones iconográficas, el

El círculo de poder de los califas omeyas de Córdoba, "Cuadernos de Madīnat al-Zahrā", 5 (2004), pp. 9-29, con interesantes apreciaciones sobre la familia omeya.

${ }^{14}$ Véanse los ejemplos seleccionados por María Jesús VIGUERA, El héroe en el contexto árabeislámico, "Cuadernos del Cemyr", I (1994), pp. 53-74.

15 Mohamed MeOUAK, Représentations, emblèmes et signes de la souveraineté politique des Umayyades d'al-Andalus d'après les textes arabes, "Acta Orientalia”, LVI (1995), pp. 78-105, recoge datos sobre algunos de los signos materiales del poder omeya andalusí, como las banderas, el trono o el parasol, además de analizar una serie de recursos retóricos al respecto. 
hecho es que no se han conservado auténticos retratos de los califas u otros dirigentes islámicos tempranos, fueran reales o inventados, con alguna notable excepción ${ }^{16}$.

Para individualizar sus rasgos personales, era necesario, por tanto, recurrir al lenguaje descriptivo, utilizado con gran variedad de cualificaciones por quienes registraron su paso por la historia. Del mismo modo que hoy los visitantes de los museos de arte occidental pueden contemplar una galeria de retratos pintados de los reyes que se sucedieron en sus propios países, el lector de una crónica árabe medieval tenía a su disposición esa misma clase de retratos, traducidos en palabras, si no en imágenes. En la cronística árabe se preservaron esta clase de descripciones con mayor o menor precisión, pero siempre con la intención de dar a conocer datos que permitieran recomponer un retrato pretendidamente fiel del soberano biografiado ${ }^{17}$. Un historiador temprano, como al-Ya'qūbī (segunda mitad del siglo III/IX), registró, aunque de forma no sistemática, apuntes sobre las características corporales de los primeros sucesores de Mahoma al frente de la comunidad islámica ${ }^{18}$.

Las descripciones recogidas por Ibn 'Idārī respecto a los príncipes omeyas de al-Ándalus se reproducen a continuación ${ }^{19}$ :

'Abd al-Rahmān I (r. 137-172/756-788) era "de talle alto, rubio, tuerto, barbilampiño, tenía un lunar en la cara y llevaba dos aladares"20.

${ }^{16}$ Así, la del califa omeya de Damasco 'Abd al-Malik b. Marwān, visible, aunque de forma muy esquemática, en las monedas acuñadas en su nombre (John WALKER, A Catalogue of the Arab-Byzantine and Post-Reform Umaiyad Coins, London, 1956, láminas VI-VIII y Chase RoBINSON, 'Abd al-Malik, Oxford, 2005, p. 50). Como se sabe, en las pinturas murales de Qușayr 'Amra existen representaciones de soberanos y príncipes, islámicos y no islámicos; v. Martín Almagro et al., Qusayr 'Amra. Residencia y baños omeyas en el desierto de Jordania, Granada, 2002 (reimpr. de Madrid, 1975), p. 60 y fig. 94; p. 66 y fig. 89 y 92; fig. 51. Más recientemente, Claude VIBERT-GuIGUE y Ghazi BISHEH, Les peintures de Qusayr 'Amra. Un bain omeyyade dans la bādiya jordanienne, Beirut, 2007, y el interesante trabajo de Garth FowDEN, Qusayr 'Amra. Art and the Umayyad Elite in Late Antique Syria, Berkeley, 2004. En al-Ándalus, la aljuba de Oña contiene también una representación icónica de un personaje real; véase Manuel CASAMAR y Juan ZoZAYA, Apuntes sobre la yuba funeraria de la Colegiata de Oña (Burgos), "Boletín de Arqueología Medieval", 5 (1991), pp. 39-60; sobre ello trabaja actualmente M. Ali de Unzaga, a quien agradezco haber llamado mi atención al respecto.

${ }^{17}$ Sobre el interés de los soberanos omeyas de Damasco por la iconografía de los sasánidas y la suya propia, G. FOWDEN, Qusayr 'Amra, 2004, p. 218 y nota 94.

${ }^{18}$ AL-YA'QūBĪ, Ta’rīj, (M. Th. Houtsma, ed.), vol. II, Leiden, 1883, p. 157 (Abū Bakr); p. 185 ('Umar) y p. 186 ('Uțānn). Hay en la misma obra referencias dispersas a los sucesivos califas, pero la atención a este tema desaparece conforme avanza el relato cronístico. Más sistemático, a este respecto, es el patriarca melkita de Alejandría SA İD B. AL-BIṬRĪQ (m. 328/940), Kitāa al-ta'rīj, vol. II, (L. Cheikho, B. Carra de Vaux, H. Zayyat, eds.), Beirut, 1909. El compendio histórico de AL-MAS ¿ūDì (s. IV/X), Kitāb al-Tanbìh wa-l-išrāf, (M. J. De Goeje, ed.) Leiden, 1967, contiene igualmente una serie de "retratos" de los soberanos islámicos.

${ }^{19}$ Las referencias a otras fuentes cronísticas que se darán en cada caso proceden del estudio historiográfico de L. Molina a su edición y traducción de $\underline{D} i k r$ bilād al-Andalus, con alguna adición esporádica.

${ }^{20}$ Bayān, II, p. 48. En Dikr bilād al-Andalus, el editor ha recurrido a Bayān, II, para reconstruir un texto con lagunas en los manuscritos. AL-NUWAYRİ, Nihāyat al-arab, ed. parcial M. Gaspar Remiro, Granada, 1917, p. 17, omite lo relativo al lunar y los aladares. Bayān, II, p. 41, ha adelantado el significado del peinado de 'Abd al-Raḥmān como señal anticipatoria de su destino como señor de alÁndalus; de ello advierte al gobernador de Ifrīqiya un judío que había servido al tío abuelo de 'Abd al-Raḥmān, Maslama b. 'Abd al-Malik, anunciador del futuro del entonces niño 'Abd al-Raḥmān. Lo mismo, en I. al-Abyārī (ed.), Ajbār mâ̂mū'a, El Cairo, 1981, p. 56, y L. Molina (ed.), Fäth alAndalus, Madrid, 1994 y trad. M. Penelas, Madrid, 2002, pp. 70/59. Más detalles sobre la predicción de Maslama, en M. MARín, 'Ilm al-nuğūm e 'ilm al-hidțān en al-Andalus, en Actas del XII Congreso de la U.E.A.I., Madrid, 1986, pp. 509-35. 
Hišām I (r. 172-180/788-796) era "de tez blanca algo rojiza y bizco"21.

Al-Hakam I (r. 180-206/796-822) era "moreno, de piel muy oscura, alto, de hermoso perfil, delgado, no se teñía"22.

'Abd al-Rahmān II (r. 206-238/822-852) era "alto, moreno, de nariz aguileña, de grandes pupilas negras, con los párpados alcoholados; tenía una gran barba teñida de aleña y de katam"23.

Muhammad (r. 238-273/852-886) era "de tez blanca algo rojiza, rechoncho y de barba abundante que teñía con alheña y katam"24.

Al-Mundir (r. 273-275/886-888) era "moreno, de pelo rizado, con huellas de viruela en el rostro; se teñía con alheña y con katam" ${ }^{25}$.

'Abd Allāh (r. 275-300/888-912) era "de tez blanca rojiza, rubio, de nariz aguileña, rechoncho; se teñía de negro" 26.

'Abd al-Rahmān III (r. 300-350/912-961) era "de tez blanca, rechoncho, de ojos azules, cuerpo proporcionado, hermoso, bello, espléndido; se teñía de negro" ${ }^{27}$.

Al-Hakam II (r. 350-366/961-976) era "de tez blanca rojiza, grandes pupilas negras, nariz aguileña, voz aguda, piernicorto, de cuerpo poderoso, cuello y antebrazos grandes; tenía la mandíbula superior saliente" 28 .

Hišām II (r. 366-399/976-1009) era “de tez blanca, ojos de azul intenso con grandes pupilas negras grandes, barbilampiño, de barba rojiza, hermoso de cuerpo y piernicorto" 29 .

A pesar de su concisión, estos retratos verbales provocaban en quienes los leían una imagen mental específica ${ }^{30}$. Es llamativo que, en la historiografía islámica,

${ }^{21}$ Bayān, II, p. 61. Lo mismo en IBN AL-AT̄îR, al-Kāmil, vol. VI, Beirut, 1965, p. 248 y ALNuWAYRĪ, Nihāya, p. 25. Dikr bilād al-Andalus, p. 118/126, añade que Hišām era zanquilargo.

${ }^{22}$ Bayān, II, p. 68. Casi idéntica descripción, en IBN AL-AṬīr, al-Kāmil, vol. VI, p. 377 y $\underline{D} i k r$, p. 124/133; resumido en AL-NUWAYRĪ, Nihāya, p. 40.

${ }^{23}$ Bayān, II, p. 81. Varía en algunos detalles el retrato que hace al-Rāzī (en IBN HAYYĀN, alMuqtabis min anbā' ahl al-Andalus (M. 'A. Makkī, ed.), Beirut, 1973, p. 22: "de hermoso perfil, nariz aguileña, pupilas grandes, elevada estatura, majestuoso, de grandes bigotes y barba, teñida de aleña"; Dikr, p. 112/145, sigue a Bayān, II. Sobre katam, v. más adelante.

${ }^{24}$ Bayān, II, p. 94. Lo mismo en IBN AL-AT̄îR, al-Kāmil, vol. VII, p. 424; $\underline{D} i k r$, p. 146/155, añade otros rasgos: "cuellicorto, de nariz aguileña, rubio y de rostro redondo".

${ }^{25}$ Bayān, II, p. 113; coincide con IBN AL-AT̄îR, al-Kāmil, vol. VII, 435 (que omite lo relativo al tinte) y $\underline{D} i k r$, p. $149-50 / 159$, que añade "de larga barba y hermosa nariz".

${ }^{26}$ Bayān, II, p. 120-21. Lo mismo en IBN AL-AT̄îr, al-Kāmil, vol. VIII, p. 73. Hay variaciones sobre esta descripción en Dikr, p. 153/163: "de un blanco rojizo, estatura media, calvo, ojos azules, nariz aguileña, se teñía con aleña”. En 'Arīb b. Sa īd (Juan CASTILLA BRAZALES, La crónica de 'Arīb sobre al-Andalus, Granada, 1992, p. 113): "tez blanca, rubicundo, de ojos azul claro y nariz aguileña. Se teñía de negro, su estatura era media, tirando a alta, y era metido en carnes".

${ }^{27}$ Bayān, II, p. 156. La Crónica anónima de 'Abd al-Rahmān III al-Nāṣir, (E. LÉVI-PROVENÇAL y E. GARCÍA GóMEZ, ed. y trad.), Granada, 1950, p. 27/89 añade que "sus piernas eran algo cortas, hasta el punto de que su estribo, por esta razón, bajaba apenas un palmo de la silla. Cuando montaba a caballo parecía de talla aventajada; pero, a pie, resultaba bastante bajo"; IBN AL-ATIīR, al-Kāmil, vol. VIII, p. 535, también menciona que al-Nāșir era piernicorto (y largo de espalda); IBN AL-JAṬīB, al-Ihạaṭa fi ajbār Garnāța (M. 'A. 'Inān, ed.), vol. III, El Cairo, 1975, p. 464, selecciona: "blanco, rubio, de rostro hermoso, corpulento, piernicorto".

${ }^{28}$ Bayān, II, p. 233. Con alguna variante, también en IBN AL-JAṬīB, al-Ihạata, vol. I, p. 478 e IBN AL-AT̄îr, al-Kämil, vol. VIII, p. 677 (donde la "voz aguda" ha cambiado a "voz potente"). Dikr, p. $168 / 179$ añade que al-Hakam tenía las mejillas tersas y la barba rala.

${ }^{29}$ Bayān, II, p. 253. Dikr, p. 174/184, añade que era rubio, rechoncho y de mirada penetrante.

${ }^{30}$ Michael COOPERSON, Images Without Illustrations: The Visual Imagination in Classical Arabic Biography, en Islamic Art and Literature (O. GRABAR y C. RoBInSON, eds.), Princeton, 2001, p. 17. 
sean casi exclusivamente los soberanos quienes merezcan ser objeto de esta clase de descripción; quizá porque así se seguía, de manera implícita, el modelo de las descripciones del aspecto físico del Profeta, de quien los califas eran sucesores ${ }^{31}$.

En su excepcionalidad, las descripciones de los príncipes omeyas de al-Ándalus los relacionan, por tanto, con las de otros monarcas islámicos que les precedieron o sucedieron, situándolos así en una categoría única. De estos retratos tan particulares cabe, en todo caso, extraer alguna consideración de conjunto.

Llama desde luego la atención que de los textos antes reproducidos se deduzca una imagen física que no siempre es complaciente con el retratado. En general, no se pretende embellecer al individuo descrito, cuyas cualidades físicas menos atractivas no se disimulan en absoluto ("rechoncho", "cuellicorto", "con huellas de viruela en el rostro", "piernicorto", etc.). Cabe suponer, pues, que los datos recogidos en la crónicas reflejen una realidad física conocida por los contemporáneos de los soberanos omeyas y trasladada a la tradición historiográfica andalusí.

Este retrato "real", aunque a veces pueda considerarse como "de cuerpo entero", puesto que subraya la proporción (o falta de ella) de sus miembros, la delgadez o la corpulencia del cuerpo, se concentra especialmente en el rostro, cuyos rasgos se detallan con cierta minuciosidad, especialmente cuando se describe "el hermoso perfil" o la "nariz aguileña" - sin olvidar la mandíbula superior saliente de al-Hakam II. El color de los ojos y del pelo o los matices de la tez completan en la mente del lector la imagen cromática de los soberanos.

En esa imagen predominan los términos relativos al cabello y la barba. Esta última, aditamento indispensable de la representación visual de los varones musulmanes, se añade a la larga cabellera en el retrato numismático de ${ }^{\circ} A b d$ al-Malik b. Marwān, en un conjunto de gran impacto visual, al que se añaden otros emblemas de dominio ${ }^{32}$. Del mismo modo, los retratos "escritos" por los cronistas orientales de los soberanos omeyas y 'abbāsíes suelen incluir referencias a la longitud, espesura y coloración de sus barbas, teñidas o canosas, naturalmente oscuras o aderezadas con artificio para parecerlo ${ }^{33}$.

Todos estos temas se reconocen en los retratos de los omeyas andalusíes, en los que interviene igualmente la cuestión del tinte de cabellos y barba que, como se ha visto, aparece por primera vez, de forma negativa, en la descripción de al-Hakam I ("no se teñía"), para hacerlo de forma contraria en la de su sucesor, 'Abd al-Rahmān II, quien se alcoholaba los párpados y se teñía la barba con aleña y katam. También siguieron esta costumbre los emires Muḥammad, al-Mundir, 'Abd Allāh y 'Abd alRaḥmān III, aunque no se menciona en los retratos del segundo y tercer califa omeya de al-Ándalus, al-Hakam II y su hijo Hišām.

${ }^{31}$ La "descripción" del Profeta se atribuye a Anas b. Mālik y, en otra versión más difundida, a ‘Alī b. Abī Țālib; véase M. CoOPERSON, Images Without Illustrations; en p. 16, Cooperson explica la ausencia de iconografía en la literatura biográfica islámica por el desfase entre la validación de los datos históricos de un personaje a través del sistema del isnād y la de una posible representación figurativa del mismo, para la cual se carecía de un protocolo similar. Es una explicación inteligente que, sin embargo, no aclara por qué no se elaboró esa misma clase de protocolo para la autentificación de las imágenes; parece evidente que el valor de la palabra escrita y sus métodos de conservación y transmisión consiguieron imponerse como el criterio cultural árabe-islámico dominante, gestionado por élites letradas que funcionaban en torno a los círculos del poder político y que organizaron muy eficazmente su reproducción social, algo que no pudieron o supieron hacer quienes se dedicaron a las artes plásticas.

${ }^{32}$ Ch. Robinson, 'Abd al-Malik, pp. 50-51. El califa lleva, en esta representación, una espada y un látigo.

${ }^{33}$ SA İ̃ B. AL-BIṬRĪQ, Kitāb al-ta rìj, vol. II, pp. 11, 27, 33, 38, 41, 42 y 43. 
La práctica del teñido de barba y cabellos se conocía en al-Ándalus desde tiempos de la conquista ${ }^{34}$; como tantas otras cosas fue traída desde Oriente. Allí era conocida en la Península Arábiga desde tiempos preislámicos, pero sólo conoció una amplia difusión tras la expansión del islam y el contacto de los primeros musulmanes con otras culturas, dando lugar a la aparición de una serie de Tradiciones Proféticas que no siempre coinciden entre sí, aunque entre ellas destaca la que atribuye a Mahoma el siguiente dicho: "El mejor tinte con el que podéis cambiar el color de vuestro pelo blanco es la aleña mezclada con katam" 35 .

La aleña (Lawsonia inermis, en árabe hinnā') se cultivaba en al-Ándalus ${ }^{36}$ y de su uso en la cosmética hay diversos testimonios, a los que puede añadirse una noticia según la cual un nieto de 'Abd al-Rạ̣mān III arrendó en cierto momento su parte de los molinos de aleña que funcionaban en Córdoba ${ }^{37}$. En cuanto al katam, que se utilizaba para oscurecer el color predominantemente amarillento o anaranjado producido por la aleña ${ }^{38}$, ha sido identificado como Phillyrea angustifolia L. y $P h$. latifolia L. (en castellano, labiérnago ${ }^{39}$ ). La combinación de aleña más katam, cuya bondad se atribuye al juicio del Profeta, es justamente la que se atribuye por la cronística a los omeyas andalusíes, todo ello en un contexto de distinciones étnicas, religiosas y sociales.

Entre estas diferenciaciones de una sociedad que está en un periodo clave de su formación, parece claro que son los árabes (o los tenidos por tales), los militares y quienes ejercen el poder político (todos ellos, en principio, del mismo origen étnico) quienes se señalan por este signo. Pero las cosas no son tan sencillas. Acabamos de ver que al-Hakam I "no se teñía", y que dentro de la casa omeya de al-Ándalus, fue 'Abd al-Raḥmān II quien primero adoptó una serie de signos visuales y fuertemente cromáticos para definir su personaje público: ojos alcoholados, barba y bigotes teñidos de una mezcla de aleña y katam. Fue este último el modelo que se perpetuó entre sus descendientes, como muchas otras cosas que se atribuyen a este príncipe omeya, organizador, según las crónicas, de una nueva administración estatal y de un estilo de vida cortesana que seguía, de lejos y a escala provincial, los patrones establecidos por sus antepasados omeyas de Damasco y por sus contemporáneos 'abbāsíes en Bagdad. En el retrato escrito de ${ }^{\circ} \mathrm{Abd}$ al-Raḥmān II se funden todos estos elementos para lograr una imagen de poder en la cual juegan tanto las apoyaturas islámicas (la relación, no explícita pero presente para quien conociera esa clase de textos, a la recomendación del Profeta sobre el mejor de los tintes y su uso por el primer califa, Abū Bakr) como otras más seculares, vinculadas a la proyección iconográfica de los soberanos como ejes del poder, parte del cual se manifestaba, como se ha visto antes a propósito de

\footnotetext{
${ }^{34}$ Recuérdese cómo Mūsà b. Nușayr impresionó tanto a los habitantes de la sitiada Mérida con los cambios de color de su barba, que pasa del blanco al rojizo y luego al negro de un día para otro, que aceptaron sus condiciones de rendición (Ajbār maŷmūia, p. 26). El carácter legendario de este episodio no impide apreciar su valor como testimonio de las diferencias culturales entre las poblaciones locales y sus nuevos señores.

${ }^{35}$ Recogido por Ibn Saed y citado por G. H. A. JUYNBOLL, Dyeing the hair and beard in early Islam. A hadìth-analytical study, "Arabica”, XXXIII (1986), p. 68. SA İD B. AL-BIṬRĪQ, Kitāb al-ta'rìj, vol. II, p. 11: Abū Bakr se teñía la barba con alheña y katam.

${ }^{36}$ Expiración GARCÍA SÁNCHEZ, Las plantas textiles y tintóreas en al-Andalus, en Tejer y vestir. De la Antigüedad al Islam (M. MARÍN, ed.), Madrid, 2001, pp. 437-8; Julia CARABAZA BRAVO et al., Árboles y arbustos de al-Andalus, Madrid, 2004, pp. 274-77.

${ }^{37}$ M. Marín, Mujeres en al-Ándalus, Madrid, 2000, p. 209. Sobre la difusión y usos de la aleña, Françoise AUBAILE-SALlENAVE, Les voyages du henné, "JATBA", 29 (1982), pp. 123-78.

${ }^{38}$ G. H. A. JUYNBOLL, Dyeing the hair, p. 50.

${ }^{39}$ J. Carabaza Bravo et al., Árboles y arbustos, pp. 318-21.
} 
‘Abd al-Malik b. Marwān, en la exhibición de sus cabellos y barba. El color de este adorno capilar no carecía de importancia: su oscuridad (mezclada con reflejos alheñados) era testimonio de una juventud y virilidad imperecederas, cualidades necesarias para afirmar el ejercicio del poder ${ }^{40}$.

Cabe contrastar estos modelos visuales con otros generados por la sociedad andalusí del siglo III/IX. El caso quizás más representativo es el del juez de Córdoba Muhammad b. Bašir ${ }^{41}$, de origen árabe (del ŷund de Egipto establecido en Beja), del que se afirma que, entre otras características, se adornaba con aleña y alcohol, lo que le valió acres censuras de algunos de sus colegas ${ }^{42}$. De un contemporáneo suyo, un sabio también de origen árabe y residente en Jaén, donde alcanzó gran reputación, se señala en una de sus biografías que vestía trajes de seda y se teñía los pies con aleña ${ }^{43}$. En ambos casos, la utilización de tintes se señala como anomalía en el mundo de los ulemas, lo cual parece significar que el uso de esta clase de alteraciones cromáticas, vinculadas a costumbres culturales árabes, se iba considerando como impropio de quienes se dedicaban a las ciencias islámicas y pretendían ocupar espacios fundamentales del control de las normativas religiosas y sociales.

Ahora bien, si los ulemas andalusíes del siglo III/IX se esforzaron por crear una imagen visual que les fuera propia, y en la cual no entraba el recurso a los tintes, ni a otras manifestaciones de lujo (como el uso de tejidos de seda), eso no quiere decir que las barbas y cabellos teñidos utilizados por los soberanos omeyas carecieran de legimitidad religiosa -recordemos el dicho del Profeta anterioremente mencionado al respecto-. Pero es evidente que un aspecto tan aparentemente nimio como el teñido de cabellos y barbas podía significar una diferenciación social notable: entre árabes y no árabes, entre sabios/altos funcionarios y otros miembros de las élites gobernantes, entre, finalmente, el espacio de la corte y el del resto de la sociedad. A partir del reinado de 'Abd al-Raḥmān II, cuando se estableció un ámbito cortesano regido por normas propias, se reproduce el mismo esquema iconográfico del soberano, del que forma parte ineludible el teñido del cabello y la barba como uno de los signos distintivos de su identidad: el monarca se caracteriza por una abundante capilaridad facial, de tonos oscuros que viran hacia un rojo anaranjado. Eso sí, el tópico historiográfico se topará, finalmente, con la indiscutible realidad de un monarca barbilampiño, al-Hakam II, y el de su heredero, Hišām II, que accede al poder siendo aún un niño ${ }^{44}$. La imagen cromática y barbada se disuelve progresivamente, al hilo de la desaparición del califato omeya de al-Ándalus.

No está de más recordar que estos retratos escritos, tan acusadamente cromáticos ${ }^{45}$, carecen de toda información sobre un elemento que no puede faltar en una representación iconográfica: la indumentaria y otros atributos visuales del

\footnotetext{
${ }^{40}$ Ha de señalarse, no obstante, que de algunos califas de Oriente se indica que tenían una barba canosa: el omeya al-Walīd b. 'Abd al-Malik y el 'abbāsí al-Ma'mūn (SA ĪD B. AL-BIṬRĪQ, Kitāb alta'rijj, vol. II, pp. 42 y 59).

${ }^{41}$ M. MARín, Nómina de sabios de al-Andalus (93-350/711-961), en Estudios onomástico-biográficos de al-Andalus, Vol. I, Madrid, 1988, nº 1554.

${ }^{42}$ M. MARín, Signos visuales de la identidad andalusí, en Tejer y vestir: de la antigüedad al islam, (M. MARÍN, ed.), Madrid, 2001, p. 167.

${ }^{43}$ Ibidem.

${ }^{44}$ Aunque de éste se diga, como se ha visto, que tenía una barba rojiza, también se afirma que, como su padre, era barbilampiño. También lo era, por otra parte, 'Abd al-Rạ̣mān I.

${ }^{45} \mathrm{El}$ color de los ojos y la tez sirve también de indicador sobre la bien conocida preferencia de los omeyas de al-Ándalus hacia la unión sexual con mujeres bereberes o procedentes del norte de la Península Ibérica.
} 
poder (como los que se encuentran en las monedas acuñadas a nombre de 'Abd al-Malik b. Marwān). Evidentemente, los cronistas no están describiendo a un "emperador desnudo", sino que esperan de sus lectores que añadan, a la imagen física que acaban de delinear, todo un conjunto vestimentario y ornamental. Así, el retrato escrito se convierte en una imagen mental mucho más completa, desgraciadamente fuera del alcance del observador actual, pero que comprendía toda una gama de formas, colores y objetos que subrayaban el ejercicio del poder soberano y funcionaban de manera decisiva en sus representaciones ceremoniales y simbólicas ${ }^{46}$. A una de estas últimas dedicaré ahora mi atención.

\section{LA INSCRIPCIÓN DEL SELLO: UN LEMA PERSONAL Y DINÁSTICO}

En las “fichas biográficas” que Ibn 'Id̄ārī dedicó a los soberanos omeyas de al-Ándalus, es frecuente que antes o después de su descripción física, figure de forma inmediata el texto grabado en su sello. Esta proximidad puede ser casual, ya que no es totalmente sistemática; sin embargo, no deja de ser significativa, ya que vincula el retrato verbal del príncipe con la expresión escrita de su personalidad. Una doble imagen se construye a partir de estos dos aspectos aparentemente alejados entre sí: el rostro del dirigente y las palabras que figuran en su sello.

El uso de esta clase de fórmulas de identificación personal procede de una antigua tradición medio-oriental, de la que formaban parte representaciones iconográficas que seguían en uso en el periodo formativo de la sociedad islámica ${ }^{47}$. Así se observa en algunas de las biografías de esa época recogidas por Ibn Sa $\mathrm{S}$ (m. 230/845), que informa, por ejemplo, de cómo el famoso juez de Kufa Šuraỵ b. al-Hārit al-Kindī (m. entre 78/697 y 99/717) tenía un sello que representaba a una palmera entre dos leones ${ }^{48}$. En el de Abū 'Ubayda b. 'Abd Allāh b. Masēùd alHudalī figuraban dos grullas; un pájaro indeterminado, en el sello de al-Ḍaḥhāk b. Muzāhim, un león sedente (en otras tradiciones, un lobo o un zorro) en el de Anas b. Mālik, un pavo real en el de Ziyād b. Abī Sufyān y un hombre portando una espada en el de 'Imrān b. al-Hușayn ${ }^{49}$. Testimonia igualmente la obra de Ibn Sa d la coexistencia, incluso en la biografía de un mismo personaje, de diferentes formulaciones iconográficas y/o escriturarias. Hasta llegar a un consenso sobre el tipo de inscripciones que convenía insertar en el sello de los musulmanes, es claro que se expresaron opiniones divergentes al respecto y que, como en muchas otras cuestiones que se estaban entonces debatiendo, lo que llegó a ser considerado como "islámico" no era más que una entre otras posibilidades que terminó por imponerse. Así, 'Umar b. al-Jațāāb se mostró decididamente contrario a que los

${ }^{46}$ Sobre el ceremonial omeya de al-Ándalus, Miquel BARCELó, El califa patente: el ceremonial omeya de Córdoba o la escenificación del poder, en Madinat al-Zahrā'. El Salón de 'Abd al-Rahmān III, Córdoba, 1995, pp. 155-175; M. MEOUAK, Représentations, emblèmes et signes, y Maribei FIERRO, Pompa y ceremonia en los califatos del Occidente islámico (s. II/VIII-IX/XV), "Cuadernos del Cemyr", 17 (2009), 125-152. Acerca de los testimonios escritos sobre la indumentaria de califas orientales omeyas y 'abbāsíes, Elisa MESA FERnÁndEZ, El lenguaje de la indumentaria. Tejidos y vestiduras en el Kitāb al-Agānī de Abū l-Faraŷ al-Ișfahān̄̄, Madrid, 2008, pp. 238-241.

${ }^{47}$ John Allan y Dominique Sourdel, Khātam, khātim, en Encyclopaedia of Islam, $2^{\mathrm{a}}$ ed., Leiden, 1978, s.v.

${ }^{48}$ IBN SA D, Kitāb al-Tabaqāt al-kabīr (E. SACHAU, ed.), Leiden, 1905-1940, vol. VI, p. 96. Sobre este personaje, cuya historicidad ha sido discutida, Etan KOHLBERG, "Shurayh" en Encyclopaedia of Islam, $2^{\text {a }}$ ed., Leiden, 1997, s.v.

${ }^{49}$ IBN SA D, Țabaqāt, respectivamente vol. VI, p. 146 y 210; vol. VII/1, p. 11, 71 y 5. 
sellos tuvieran inscripciones en árabe, y su hijo `Abd Allāh prohibió expresamente la utilización de frases coránicas en ellos ${ }^{50}$. Algunos de quienes se vieron censurados por hacerlo así recurrieron a la inscripción de su propio nombre en el sello, costumbre que llegó a ser la más generalizada, aunque incorporando a ella breves fórmulas de carácter religioso, con citas coránicas o de la Tradición Profética, o parte de la profesión de $\mathrm{fe}^{51}$. Las representaciones icónicas, presentes entre las primeras generaciones de musulmanes, fueron desapareciendo gradualmente, tal como ocurrió en la numismática, en la que las acuñaciones figurativas anteriores a 'Abd al-Mālik b. Marwān y aún bajo su reinado dieron paso en ese mismo periodo a monedas exclusivamente textuales ${ }^{52}$.

Algunos textos registraron las inscripciones de los sellos de los califas, ya desde los inmediatos sucesores de Mahoma ${ }^{53}$. Ninguno de ellos, por supuesto, contenía representaciones figurativas y en su inmensa mayoría reflejan formulaciones de carácter religioso, a menudo con resonancias coránicas. Al haber desaparecido prácticamente el rastro material de estos sellos, es imposible saber si la tradición historiográfica, tanto en Oriente como luego en al-Ándalus, introdujo versiones más "islamizadas" de una realidad que podría haber sido algo distinta de la que vino a predominar en la cronística. Pero al ser esa transmisión historiográfica la única de que se dispone, es evidente que se ha de trabajar sobre ella, lo que, como se verá a continuación, arroja algunos puntos de interés.

En la relación de los sellos de los califas transmitida por al-Mas' ${ }^{\mathrm{u}} \mathrm{d} \mathbf{i}$ (m. 345/956) en su Kitāb al-Tanbīh wa-l-išra $f^{54}$ se aprecia una preferencia general, aunque no exclusiva, por lemas de carácter religioso, que con frecuencia tienen ecos coránicos. El nombre propio del califa aparece en algunas ocasiones, pero está lejos de ser una norma general, como la que se observa en los sellos de los príncipes omeyas de al-Ándalus ${ }^{55}$.

No sorprende comprobar, en esa lista de lemas sigilográficos, que el adoptado por el tercero de los califas sucesores (rāšidūn) de Mahoma, el omeya 'Utmān b. "Affān (ämantu bi-llāh mujliș ${ }^{a n}$ - "en Dios creo sinceramente") ${ }^{56}$ reaparezca, en la misma forma o con algunas variantes, en los sellos de varios califas omeyas de Damasco,

\footnotetext{
${ }^{50}$ Ibidem, vol. VI, p. 180; vol. VII/1, p. 11 y vol. VII/2, p. 4.

${ }^{51}$ Así se observa en algunos de los ejemplares más tempranos que han llegado a nuestros días (Ludvik Kalus, Catalogue of Islamic Seals and Talismans, Ashmolean Museum Oxford, Oxford, 1986, pp. 4-6).

${ }^{52}$ Aun así, se conserva (en el Museo Arqueológico de Estambul) un sello atribuido a 'Abd alMalik en el que, junto al texto de la profesión de fe en árabe, figuran representaciones zoomórficas y una letra del alfabeto griego; véase Oleg GRABAR, The Formation of Islamic Art, New Haven, 1973 , p. 95 y figura 21. Grabar sugiere que el sello pudiera datarse antes de la reforma numismática del califa y que tuviera carácter privado.

${ }^{53}$ El cual, según algunas tradiciones, tenía un sello en el que se leía Muhammad rasūl Allāh, sello que se perdió en época de 'Utmān (J. AlLAN, "Khātam").

${ }^{54}$ Sobre la obra historiográfica de al-Mas'ūīi, Tarif KHALIDI, Islamic Historiography. The Histories of Mas'ūdì, Albany, 1975. Por otra parte, Patricia CRONE y Martin Hinds, God's Caliph. Religious Authority in the First Centuries of Islam, Cambridge, 1986, p. 25, nota 2, consideran que la información de al-Mas ū $\mathbf{u}$ ī sobre los sellos califales carece de credibilidad, aunque no queda claro si se refieren únicamente a los inmediatos sucesores de Mahoma o al resto de los califas omeyas y 'abbāsíes repertoriados en la obra de al-Mas 'ū $\mathrm{u}$ ì.

${ }^{55}$ Se menciona el nombre del califa (o su laqab honorífico) en los casos de Umar b. al-Jatțāb entre los rāšidūn; ninguno entre los omeyas de Damasco; entre los primeros 'abbāsíes, al-Manșür, Hārūn al-Rašīd, al-Ma'mūn, al-Wātiq, al-Mutawakkil, al-Muntașir, al-Musta’ēn y al-Mu tazz (AL-MAS' ŪDĪ, Tanbīh, pp. 289, 343, 346, 352 y 361-65).

${ }^{56}$ Ibidem, p. 293
} 
como Marwān b. al-Hakam, 'Abd al-Malik b. Marwān, Sulaymān b. 'Abd al-Malik y 'Umar b. 'Abd al- ${ }^{\circ}$ Azìz ${ }^{57}$. Los omeyas, conscientes del poder propagandístico de esta clase de formulaciones, eligieron para ello frases que, aunque necesariamente breves, no dejaran dudas sobre su fidelidad al credo islámico; a la fórmula antes citada pueden añadirse otras como lā quwwa illā bi-llāh, rabbu-nā Allāh, al-'izza li-llāh ("no hay fuerza sino en Dios", "Dios es nuestro señor", "De Dios es la gloria"), etc. ${ }^{58}$

Cabría esperar que los omeyas andalusíes hubieran seguido elecciones similares para los lemas de sus sellos, recogiendo así las tradiciones de la familia soberana a la que pertenecían y cuyo poder habían continuado en el extremo occidental del mundo islámico. Sin embargo, los textos que, según Ibn 'Idāāī y otros cronistas, estaban impresos en sus sellos, aunque presentan una similar referencia religiosa, se inclinan por formulaciones diferentes que, en alguna ocasión, tienen más que ver con las usadas por sus contemporáneos (y enemigos teóricos) ‘abbāsíes que con sus propios antepasados.

Veamos a continuación cuáles fueron los lemas inscritos en los sellos de los omeyas andalusíes. De 'Abd al-Raḥmān I se tienen dos versiones diferentes, aunque ambas se continuarán en sus sucesores. La primera de ellas es la que conoció una mayor fortuna: 'Abd al-Rahmmān bi-qad̄a Allāh rạd din ("Abd al-Raḥmān está satisfecho con el decreto de Dios") ${ }^{59}$, pero también se encuentran ecos de la segunda en los sellos de algunos soberanos omeyas: bi-llāh yasta'īn 'Abd al-Raḥmān wa-bi-hi ya tașim ("a Dios pide ayuda y en Él se refugia 'Ảbd al-Raḥmān”), esta vez con una referencia coránica más evidente que en el caso anterior ${ }^{60}$.

Se da la extraordinaria circunstancia de que se ha conservado un precinto de plomo con el nombre del primer emir omeya de al-Ándalus, al que sigue lo que parece ser un texto de carácter religioso. A pesar de las dificultades de su lectura, cuyo autor la ofrece con muchas dudas, lo que puede afirmarse es que no tiene nada que ver con las dos fórmulas que se acaban de citar, puesto que dice: al-amìr / Abd al-Rahmān bn /Mu'āwiya hasuna/ahsana (¿) / fi sabìl Allāh / lā yuglab / wa-lā yahib ("el emir 'Abd al-Raḥmān $\dot{b}$. Muēâiya se esfuerza con buen hacer en / la causa de Dios sin dejarse vencer / ni amedrentar" $)^{61}$.

Nada similar se encuentra en los lemas sigilográficos preservados por la cronística para el resto de los soberanos omeyas hasta finales del siglo IV/X. La discrepancia entre la inscripción de este precinto y los documentos textuales puede deberse a varias razones, ninguna de las cuales pasa de ser hipotética: es posible suponer, por ejemplo, que el sello del príncipe se utilizase únicamente para validar los documentos de su cancillería, mientras que para esta clase de precintos ${ }^{62}$ se emplearan tanto otros materiales (el plomo), como fórmulas diferentes. Hay que contar también con la posibilidad de que los textos históricos hayan adjudicado a 'Abd al-Raḥmān I dos de los lemas vinculados a sus sucesores, es decir, que se hubiera proyectado hacia atrás la información disponible para omeyas posteriores, de manera que el iniciador del poder dinástico omeya en al-Ándalus no sólo no careciese de esa importante señal de identificación sino que, de algún modo, marcase la tendencia dominante entre sus sucesores.

\footnotetext{
${ }^{57}$ Ibidem, pp. 312, 316, 319 y 320.

${ }^{58}$ Wadād AL-QĀḌ̄, The Religious Foundation of Late Umayyad Ideology and Practice, en Saber religioso y poder político en el Islam, Madrid, 1994, pp. 231-273.

${ }^{59}$ Bayān, II, p. 48.

${ }^{60} \underline{D} i k r$, p. 110/118. CoRÁn, ed. y trad. J. Cortés, Barcelona, 1999, IV, 146 y 175.

${ }^{61}$ Tawfiq IBRAHIM, Un precinto a nombre de 'Abd al-Rahmmān I, "Al-Qanțara”, XVI (1995), pp. 143-145.

${ }^{62}$ Ibidem, p. 145: se trataría de una especie de marca oficial para un suministro militar, identificado, por las muescas que lleva en su lado no epigráfico, con una cota de mallas.
} 
Es ésta, como ya he mencionado, la que se inicia con el nombre propio del príncipe, seguida de la expresión bi-qaḍā' Allā $h$ rā $d^{i n}$. Se atribuye su presencia en los sellos de 'Abd al-Rahmān II, Muhammad, al-Mundir, 'Abd Allāh, 'Abd al-Rahmān III y al-Hakam II $^{63}$. De los diez soberanos omeyas que se están teniendo aquí en cuenta, desde 'Abd al-Raḥmān I a Hišām II, siete, por tanto, mantuvieron este lema ${ }^{64}$.

Sólo en el caso de 'Abd al-Rahmān II se explican las circunstancias de su adopción. Al inicio de su reinado, según İbn 'Idārīi, tenía un sello con su nombre. Este sello se perdió, y entonces el emir ordenó que se volviera a grabar el sello de su antepasado 'Abd al-Raḥmān (I); el encargado de cumplir la orden, el eunuco Nașr ${ }^{65}$, envió a buscar al poeta y amigo del emir, ‘Abd Allāh b. al-Šamir, y le consultó sobre el texto que habría de inscribirse en el sello. Ibn al-Šamir improvisó entonces dos versos: "El sello del nuevo reinado / que refrendará las órdenes ante el pueblo // será: "El adorador del Clemente ('äbid al-Rahmānn) / está satisfecho con el decreto de Dios" (bi-qadāa' Allāh $\left.r \bar{a} d^{i n}\right)$. Los versos gustaron tanto al soberano que los aceptó como lema para su sello ${ }^{66}$.

La anécdota tiene todas los visos de haber sido construida para realzar la figura del poeta Ibn al-Šamir y su proximidad al soberano, aunque tampoco es posible negar por completo su verosimilitud. Cabe imaginar que Ibn al-Šamir, miembro del círculo cortesano de poetas y astrólogos que adornaban el entorno del príncipe, hubiera conocido las tradiciones relacionadas con el sello de 'Abd al-Rạ̣mān I, empleando entonces su talento poético para producir un texto del agrado de su real patrono.

Se ha dicho más arriba, sin embargo, que las tradiciones sobre el sello del primer omeya andalusí son divergentes y que su historicidad es dudosa. Estas dudas se acentúan ante un dato del Muqtabis de Ibn Hayyan: tras reproducir el texto del sello de

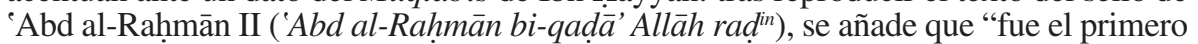
que lo hizo grabar"67. Si se acepta esto como cierto (y ha de recordarse que los textos del Muqtabis referidos a 'Abd al-Rahmān I no se han conservado), se refuerza la posibilidad, antes apuntada, de que en algún momento de la transmisión historiográfica se atribuyera al primero de los omeyas andalusíes lo que luego se convirtió en lema de la mayoría de sus sucesores y cuya introducción dataría de la época de 'Abd al-Raḥmān II.

Sobre esta concisa fórmula y su carga ideológica cabe hacer otras consideraciones. No obstante la pretendida intervención personal de Ibn al-Šamir, es evidente que esta clase de formulaciones se inscribían en un contexto mucho más amplio de proyección de los signos del poder político y religioso, inscritos sobre soporte numismático, epigráfico, textil (las inscripciones del tịāa) o cerámico ${ }^{68}$. El conjunto de lo que podría llamarse un "estado caligráfico" producía mensajes textuales de gran potencia, cuya expresión estaba limitada por las necesidades del soporte, de manera que había que buscar la manera de reducir el contenido, sin perder su eficacia, para adaptarse al continente ${ }^{69}$.

${ }^{63}$ Bayān, II, p. 81, 113, 156 y 233; Dikr, p. 146/155. No se menciona el sello del emir 'Abd Allāh en Bayān II, pero sí en $\underline{D} i k r$, p. 153/163.

${ }^{64}$ Hay discrepancia entre las fuentes respecto al emir Muhammad, cuyo sello tiene este lema en Dikr, p. 146/155, pero no en Bayān, II.

${ }^{65}$ Joaquín VALlVÉ, Naṣr, el valido de 'Abd al-Rahmānn II, “Al-Qanțara”, VI (1985), pp. 179-197.

${ }^{66}$ Bayān, II, p. 81; Dikr, p. 137/146; véase Elías TERÉs, Ibn al-Šamir, poeta-astrólogo en la corte de 'Abd al-Rahmmān II, "Al-Andalus", XXIV (1959), p. 453.

${ }^{67}$ IBN HִAYYĀN, Al-Muqtabis, p. 22.

${ }^{68}$ Miquel BARCELÓ, Al-Mulk, el verde y el blanco. La vajilla califal omeya de Madīnat al-Zahrā', en La cerámica altomedieval en el sur de al-Andalus (A. MALPICA CUELLO, ed.), Granada, 1993, pp. 293-299.

${ }^{69} \mathrm{El}$ "estado caligráfico" remite a Brinkley MESSICK, The Calligraphic State. Textual Domination and History in a Muslim Society, Berkeley, 1993, sobre la sociedad yemení en los siglos XIX y XX; véanse pp. 241-242, sobre los sellos de los imāmes yemeníes. 
En ese sentido se ha estudiado la epigrafía de la mezquita aljama de Córdoba, partiendo de la premisa de que la selección de aleyas coránicas que se inscribieron en ella no era arbitraria. En una primera aproximación a ese tema, S. Calvo Capilla ha examinado las inscripciones del área de la maqșūra (ampliación de al-Hakam II), llegando a la conclusión de que en muchos casos se han abreviado o mutilado las aleyas coránicas utilizadas, suprimiendo las referencias al libre albedrío para así imponer las opiniones de la escuela jurídica mālikí sobre la predestinación, totalmente contrarias a las de mu ${ }^{\circ}$ tazilíes y masarríes ${ }^{70}$. Su propuesta ha sido debatida por M. A. Martínez Núñez ${ }^{71}$, con dos argumentos: el primero, que la omnipresencia de la escuela mālikí ha de matizarse en época de 'Abd al-Raḥmān III, quien permitió una cierta diversidad de opiniones religioso-jurídicas ${ }^{72}$; el segundo, la existencia en la mezquita cordobesa de inscripciones epigráficas (que cita, localiza y traduce) que reproducen aleyas habitualmente interpretadas como favorables a la existencia del libre albedrío.

Esta discusión tiene también algo que ver con los sellos de los soberanos omeyas. Las interpretaciones que se acaban de presentar de forma muy resumida se refieren en especial al siglo IV/X, que es cuando se produce la condena oficial de las doctrinas masarríes bajo `Abd al-Raḥmān $\mathrm{III}^{73}$. Pero los debates planteados por los qadaríes y los mu tazilíes de Oriente en torno al libre albedrío habían penetrado en al-Ándalus mucho antes, precisamente bajo el reinado de 'Abd al-Rahmān II, en la primera mitad del siglo III/IX, y conocieron una cierta difusión en los medios intelectuales del momento ${ }^{74}$. M. 'A. Makkī ha situado esta difusión en el marco de los intereses personales de 'Abd al-Rahmān II, "entusiasta por todos los aspectos de la cultura y civilización "irāqíes"75, lo que explicaría su tolerancia inicial hacia las ideas mu tazilíes. Sin embargo, y también según Makkī, las circunstancias políticas y religiosas, tanto en Oriente como en al-Ándalus, llevaron al emir al convencimiento de que era necesario evitar la expansión de ese ideario y reforzar las opciones contrarias a él, convertidas así en doctrina ortodoxa apoyada por el poder político.

Si se da por buena esta interpretación, la adopción por 'Abd al-Raḥmān II del lema sigilográfico 'Abd al-Rahmān bi-qad̄̄' Allāh radin podría relacionarse con la necesidad de reafirmar posiciones anti-mu tazilíes, para así reivindicar la conformidad con los decretos divinos y, en consecuencia, emitir un mensaje de estabilidad y unidad comunitaria. Si el príncipe hacía constar su aceptación del destino que le había correspondido, era de esperar que todos los miembros de la comunidad bajo su mando recibieran ese mensaje como ejemplo y lo siguieran. La utilización política de

\footnotetext{
${ }^{70}$ Susana Calvo CaPIlla, El programa epigráfico de la Mezquita de Córdoba en el siglo X: un alegato a favor de la doctrina mālikí, "Qurțuba", 5 (2001), pp. 17-26 y, recientemente, S. CALVO CAPILlA, Justicia, misericordia y cristianismo: una relectura las inscripciones coránicas de la Mezquita de Córdoba en el siglo X, "Al- Qanțara”, XXXI (2010), pp. 149-187 (aunque los temas ahora tratados no tienen relación con el que aquí nos ocupa).

${ }^{71}$ María Antonia MARTínez NúÑ̃z, El Corán en los textos epigráficos andalusíes, en El Corán ayer y hoy. Perspectivas actuales sobre el Islam. Estudios en honor al profesor Julio Cortés (M. HeRnANDO DE LARRAMENDI y S. PEÑA MARTín, coords.), Córdoba, 2008, pp. 125-144, 131-134.

${ }^{72}$ Se basa para ello en Maribel FIERro, La política religiosa de 'Abd al-Rahmān III, "Al-Qanțara", XXV (2004), pp. 119-156, quien explica, no obstante, que esta diversidad ideológica estuvo bien controlada por el califa, que la utilizó con fines políticos.

${ }^{73}$ M. FIERRO, La heterodoxia en al-Andalus durante el periodo omeya, Madrid, 1987, pp. 113-118 y 132-140 y La política religiosa, pp. 133-136.

${ }^{74}$ Sobre la predestinación/libre albedrío en el Corán y desarrollos posteriores, D. V. FroLOV, Freedom and Predestination, en Encyclopaedia of the Qur'ān (J. D. MACAULIFFE, ed.), II, Leiden, 2002, 267-271, y la bibliografía citada.

${ }^{75}$ Maḥmūd 'Alī MAKKĪ, Ensayo sobre las aportaciones orientales en la España musulmana y su influencia en la formación de la cultura hispano-árabe, Madrid, 1958, p. 214.
} 
la controversia religiosa entre partidarios de la predestinación o del libre albedrío se manifiesta aquí de forma meridiana: el lema del soberano, que refrenda sus órdenes y documentos, pretende asegurar la adhesión de los musulmanes hacia el orden constituido, presidido por la voluntad divina, hacia la que no es posible ofrecer resistencia ${ }^{76}$.

El lema persiste entre la mayor parte de los príncipes omeyas de al-Ándalus, y cabe interpretar esta tendencia como parte del programa ideológico de la dinastía, expresado en otras expresiones visuales y textuales, como las identificadas por S. Calvo, para el siglo IV/X, en la mezquita aljama de Córdoba, ya mencionadas. No se trata, quizá, tanto de un "alegato" a favor del mālikismo imperante, como de una tradición bien asentada de proyección de mensajes favorables a una ideología que beneficiaba por igual a los soberanos y a las élites intelectuales que los apoyaban -entre las cuales, por supuesto, también había divergencias y luchas internas.

El segundo de los textos inscritos en los sellos de los príncipes omeyas de al-Ándalus tiene otras características. En primer lugar, se atribuye en exclusiva a los inmediatos sucesores de 'Abd al-Rahmān I, Hišam I y al-Hakam I. Vuelve a aparecer en el texto de Ibn 'Idāāī referido al emir Muḥammad y al califa Hišām II, pero en ambos sucede, como ocurría con 'Abd al-Raḥmān I, que se ofrecen alternativamente, según las fuentes, los dos lemas recurrentes en la dinastía.

Al instaurador del poder omeya en la Península Ibérica se atribuye, como ya se ha visto, un sello que llevaba la siguiente inscripción: bi-llāh yasta 'īn 'Abd al-Rahmān wa-bi-hi ya tașim ("a Dios pide ayuda y en Él se refugia 'Abd al-Rahmān"). El de su hijo y sucesor Hišām rezaba así: bi-llāh yatiq 'abdu-hu Hišām wa-bi-hi ya tașim ("en Dios confía su siervo Hišām y en Él se refugia") ${ }^{77}$. Del sello de al-Hakam I hay tres versiones casi coincidentes. La que reproduce Ibn 'Idāri es idéntica a la de su padre: bi-llāh yatiq 'abdu-hu al-Hakam wa-bi-hi ya tașim ${ }^{78}$.

Parece, por tanto, bastante claro que este lema cayó en desuso tras la implantación por 'Abd al-Raḥmān II del que luego se convirtió en preponderante bandera textual de su dinastía (aun con su alternativa aparición en los sellos del emir Muhammad y de Hišām II $^{79}$ ). Llama la atención, por otra parte, que variantes bastante similares de este lema omeya andalusí puedan encontrarse entre los que se atribuyen a los califas 'abbāsíes al-Manșūr (Allāh țiqat Muhammad wa-bi-hi yu'min - "Dios es el apoyo de Muhammad y en Él cree"), Hārūn al-Rašìd (bi-llāh yatiq Hārūn - "En Dios confía Hārūn"), al-Ma'mūn (Allāh tiqqat 'Abd Allāh wa-bi-hi yümin - "Dios es el apoyo de "Abd Allāh y en Él cree") y al-Wātiq (Allāh tiqat al-Wātiq - "Dios es el apoyo de al-Wātiq"), mientras que sólo aparece algo semejante en el sello de uno de los omeyas de Damasco, Mueāwiya b. Yazīd (bi-llāh tíqat Mu'āwiya) ${ }^{80}$.

Esta relación entre los sellos de algunos omeyas andalusíes y algunos califas 'abbāsíes puede parecer tenue, pero se vincula a una de las aleyas coránicas más

\footnotetext{
${ }^{76}$ Ignaz GOLDZIHER, Le dogme et la loi de l'Islam, Paris, 1920, pp. 77-79, atribuye a los omeyas de Oriente una política consciente de apoyo a las doctrinas favorables a la predestinación, con el objeto de asegurar la sumisión de sus súbditos (M. MAKKĪ, Ensayo, p. 210, nota 2, cita este texto de Goldziher por otra edición). Una reciente interpretación del determinismo de los omeyas en Patricia Crone, Medieval Islamic Political Thought, Edinburgh, 2004, p. 35.

${ }^{77}$ Bayān, II, p. 61 y Dikr, p. 118/126.

${ }^{78}$ Bayān, II, p. 68. IBN HẹAYĀN, Al-Sifr al-țānī min Kitāb al-Muqtabis (M. 'A. MAKKĪ, ed.), alRiyāḍ, 2003, p. 187, introduce una pequeña variante: bi-llāh yatiq al-Hakam wa-'alay-hi yatawakkil ("En Dios confía al-Hakam y a Él se encomienda"). Dikr, p. 124/133, sigue a Bayān, II, omitiendo 'abdu-hu.

${ }^{79}$ Bayān, II, p. 94 y 254.

${ }^{80}$ AL-MAS' ŪDİ, Tanbīh, respectivamente pp. 343, 346, 352, 361 y 307.
} 
difundidas ${ }^{81}$, en la que Dios se ofrece al creyente como firme y fiable asidero y apoyo: al confiar plenamente en Él (y, como añaden los sellos andalusíes de los omeyas, refugiarse y aferrarse a Él), el mensaje del sello principesco es una proclamación muy específica de su legitimidad religiosa. No es casual que este mensaje fuera adoptado, en una formulación tan próxima, por omeyas de Córdoba y 'abbāsíes de Bagdad; cabe recordar a este propósito las similitudes que se han encontrado entre los programas epigráficos de ambas dinastías ${ }^{82}$ y quizá deducir de estas coincidencias una semejante aproximación, con sus naturales adaptaciones a las circunstancias locales, hacia los signos de identificación del poder soberano islámico. Es también notable que los omeyas andalusíes recurrieran a un repertorio mucho más limitado de esta clase de fórmulas que el utilizado por sus antecesores de Damasco o por los 'abbāsíes, como si, aparte de las consideraciones que se vienen haciendo a este respecto, se hubiera dado una voluntad de identificar a la dinastía con un único lema (o, a lo sumo, dos).

Del sello del emir Muhammad existen, como se ha visto, dos versiones; sobre ello hay alguna aclaración de interés, puesto que se nos dice que una de ellas figuraba en su sello privado (naqš jātami-hi l-jāṣș), mientras que la otra estaba en su sello oficial (al-jātam al-'àmm); significativamente, ésta última es la mayoritaria entre los príncipes omeyas (Muhammad bi-qad̄a' Allāh ră $\left.d^{i n}\right)^{83}$. La coexistencia de sellos privados y públicos no ha de extrañar; responde a las diferentes esferas de acción del soberano y la necesaria (aunque no siempre bien distinguida) diferenciación entre sus asuntos personales y la gestión del tesoro público y otras funciones de la administración estatal. Pero sólo se ha conservado noticia de este caso y del de "Abd al-Rahmmān III, de quien se dice que además de su sello "público", ya mencionado, llevaba otro en un dedo, cuya inscripción era "A Dios solicita la victoria 'Abd al-Raḥmān al-Nāṣir" (bi-llāh yantașir 'Abd al-Rahmān al-Nāșir) ${ }^{84}$.

Este último lema cae fuera de todos los esquemas vistos hasta ahora para los omeyas de al-Ándalus, aunque pueden encontrársele paralelos, de nuevo, entre los usados por los 'abbāsíes, que en varios casos utilizaron su sobrenombre honorífico (laqab) como punto de partida textual para el lema de su sello, jugando con las posibilidades de la lengua árabe para identificar las raíces consonánticas presentes en el vocabulario elegido. Hemos visto ya un ejemplo, el del califa al-Wātiq (Allāh tiquat al-Wātiq); puede observarse el mismo fenómeno en al-Mutawakkil ( $\hat{Y}$ à far alà Állāh yatawakkil - "A Dios se encomienda al-Mutawakkil") y en al-Muntașir (Muhammad bi-llāh yantasir - "A Dios solicita la victoria al-Muntasir") ${ }^{85}$. Este último es idéntico al de 'Abd al-Rahmān III, pero su precedencia cronológica (al-Muntașir reinó en 247248/861-862) no significa gran cosa, si no es como antecedente de una característica que sólo en el siglo IV/X, cuando se instaura el califato omeya en al-Ándalus y el soberano adopta un título honorífico, pudo tener un sentido real.

¿Era este segundo sello, el que el califa 'Abd al-Rahmān III llevaba en un anillo, un sello privado, como el de su antepasado el emir Muḥammad? Nada dice el

\footnotetext{
${ }^{81}$ CORÁN, II, 256: "No cabe coacción en religión. La buena dirección se distingue claramente del descarrío. Quien no cree en los țāgūts y cree en Dios, ese tal se ase del asidero más firme (al-'urwa al-wutqà) un asidero irrompible. Dios todo lo oye, todo lo sabe".

${ }^{82}$ M. A. MARTíneZ NúÑEZ, Sentido de la epigrafía omeya de al-Andalus, en El esplendor de los omeyas cordobeses. La civilización musulmana de Europa Occidental (M. J. ViGUERA MoLÍNS y C. CASTILlO, coords), Granada, 2001, pp. 408-417 (esp. pp. 412 y 414) y El Corán en los textos epigráficos, pp. 129-30.

${ }^{83}$ Dikr, p. $146 / 155$.

${ }^{84}$ Ibidem, p. 159/169-70.

${ }^{85}$ AL-MAS'̄̄Dİ, Tanbìh, pp. 362 y 363.
} 
texto que lo reproduce sobre este particular, pero parece difícil creer que, una vez proclamada su nueva condición de amìr al-mu'minīn ${ }^{86}$ y tras la adopción del nombre honorífico de "al-Nāsirir", una formulación tan claramente vinculada a su propia persona y a su posición no fuera utilizada de forma pública al menos en determinadas situaciones. Desgraciadamente, carecemos de información documental al respecto; tampoco hay datos sobre otros sellos del mismo carácter utilizados por sus sucesores en el califato, que adoptaron la misma clase de títulos honoríficos, práctica usual entre los 'abbāsíes desde el segundo de sus califas, al-Manșūr, y que no utilizaron los omeyas de Damasco ${ }^{87}$.

Entre los omeyas de al-Ándalus (como en el resto del mundo árabe-islámico de su tiempo), la inscripción del sello formaba parte de su retrato público, constituido por fórmulas textuales cuidadosamente seleccionadas, puesto que expresaban un mensaje inéquivoco sobre la figura del soberano y su lugar preeminente como receptor del favor divino, cuyo decreto aceptaba sin fisuras y en cuyo apoyo confiaba para dirigir la comunidad a su cargo. Puesto que no se han conservado documentos oficiales de esta época, ni otros datos relacionados con ellos, no es posible saber cómo funcionaba la impresión del sello califal en la correspondencia emitida por la cancillería cordobesa (sin duda un aparato burocrático de gran complejidad y abundancia), cómo se controlaba su uso, quién o quiénes lo rubricaban -si lo hacían-, y cuál fue, en realidad, la intervención del soberano en el empleo de su sello. Cabe simplemente suponer que el lema de cada reinado servía para distinguir la documentación emitida en su nombre, quizá también señalada por el uso de tintes exclusivos u otras marcas que pudieran validar su origen.

Lo que sí está claro, por otro lado, es que el sello tenía un valor simbólico de carácter tan acusadamente político como religioso, y que era un legado imprescindible para la continuación dinástica. De ello hay dos ejemplos notables en la cronística sobre al-Ándalus: ambos se sitúan en un momento de dificultades para la sucesión de los omeyas, por lo cual no es casual que se haya conservado su registro historiográfico.

El primero de estos casos concierne a la sucesión de ‘Abd al-Rahmān I. En su lecho de muerte, el emir encomienda a uno de sus hijos, 'Abd Allāh (luego llamado al-Balansī), que entregue al primero de sus dos hermanos, Hišām y Sulaymān, que llegue a Córdoba (Hišām se hallaba en Mérida y Sulaymān en Toledo) "el sello y el poder" (al-jâtam wa-l-amr), puesto que a ambos adornaban suficientes cualidades para sucederlo ${ }^{88}$. Como es sabido, fue Hišām quien se adelantó en llegar a la capital, pero antes de entrar en ella se instaló en la Ruṣāfa, temeroso de que su hermano `Abd

${ }^{86}$ M. FIERRo, Sobre la adopción del título califal por 'Abd al-Rahmān III, "Sharq al-Andalus", 6 (1989), 33-42.

${ }^{87}$ C. E. Bosworth, Lakab, en Encyclopaedia of Islam, $2^{\text {a }}$ ed., Leiden, 1986, s.v., p. 620. Sobre títulos califales en soporte epigráfico, M. A. MARTínEZ NúÑ̃E, La epigrafía del Salón de 'Abd alRahmān III, pp. 144-46. Antes de la adopción por 'Abd al-Raḥmān III del laqab "al-Nāșir li-dīn Allāh", la cronística sólo registra la atribución, a Hišām I, del sobrenombre "al-Riḍa”, vinculado a su carácter piadoso y similar, en sus funciones, a fórmulas como las empleadas para los califas Abū Bakr (al-Șiddīq) o 'Umar (al-Fārūq). Es curioso, no obstante, que en la obra de AL-DAHABĪ, Siyar a'lām al-nubalā', vol. VIII (N. HAMDĀN, ed.), Beirut, 2001, pp. 253 y 263, se afirme que al-Hakam I llevaba el laqab "al-Murtadà" y el emir Muhammad, el de "al-Amīn". Como en este último caso cita al-Dahabī la autoridad de al-Yasa ' b. Hazm, es posible que también en el primero la información proceda del mismo autor, sobre el cual M. FIERRO, La falsificación de la historia. Al-Yasa' b. Hazm y su Kitāb al-Mugrib, “Al-Qanțara”, XVI (1995), pp. 15-41.

${ }^{88}$ Bayān, II, p. 61. Sobre las circunstancias de la sucesión de 'Abd al-Raḥmān I, véanse E. LÉVIPRovenÇAL, España musulmana hasta la caída del califato de Córdoba, en Historia de España (dirigida por Ramon MENÉNDEZ PIDAL), vol. IV, Madrid, 1957, pp. 91-83 y Eduardo MANZANO MORENO, Conquistadores, emires y califas. Los omeyas y la formación de al-Andalus, Barcelona, 2006, p. 195. 
Allāh, dueño del alcázar y el Tesoro, le ofreciera resistencia; no fue así, porque `Abd Allāh salió a recibir a Hišām, "lo saludó como califa, le hizo entrega del sello, como le había encargado su padre, y lo hizo entrar en el alcázar"89.

Es fácil identificar, en este breve texto, los atributos inmateriales y materiales del poder omeya andalusí: el sello que refrenda las órdenes soberanas, el palacio (desde donde se redactan, ejecutan y distribuyen esas órdenes), y el tesoro, público y privado. Todo ello estaba en manos de 'Abd Allāh, y razones tenía Hišām para no tenerlas todas consigo a su llegada a Córdoba ${ }^{90}$. Para el cronista, como ya señaló hace tiempo E. Lévi-Provençal, el sello era la insignia misma de la soberanía y su valor, equiparable al de todo el contenido del Tesoro ${ }^{91}$.

Igualmente significativo es el segundo momento histórico en el que el sello se transmite como símbolo de poder. Se trata de la sucesión del emir 'Abd Allāh, que designó como heredero, por encima de cualquiera de sus hijos, a su nieto 'Abd alRaḥmān b. Muhammad (cuyo padre, por cierto, había sido asesinado por uno de sus hermanos, Mutarrif, con la implícita aprobación de 'Abd Allāh). Una vez seleccionado como heredero, el futuro 'Abd al-Rahmān III vivió en el alcázar cordobés con su abuelo, sin compartir esa residencia con sus tíos paternos, posibles competidores por la herencia dinástica. Cuando el emir 'Abd Allāh cayó enfermo y presintió el final de sus días, entregó a su nieto su sello, en lo que se entendió como inéquivoca muestra de la transmisión de su derecho a la sucesión ${ }^{92}$.

Como imagen escrita, el sello identifica la individualidad del soberano, cuyo nombre personal (ism 'alam) figura en todos ellos. Pero es también un lema dinástico, que se reproduce con escasas variantes y envía un potente mensaje cargado de significados religiosos y políticos. En el conjunto del retrato real, no es de extrañar que la tradición historiográfica dedicada a los omeyas de al-Ándalus conservara el recuerdo de estas formulaciones, íntimamente relacionadas con su papel como conductores de la comunidad a su cargo. En los millares de documentos, hoy desgraciadamente perdidos, que debió de producir la cancillería cordobesa, el lema sigilográfico de cada emir o califa servía, sin duda, para dar fe de su legitimidad como soberano, engarzada en su continuidad dinástica.

Fecha de recepción del artículo: Junio 2010

Fecha de aceptación y versión final: Julio 2010

${ }^{89}$ Bayān, II, p. 62. El uso anacrónico del término "califato" (en el texto árabe: sallama 'alay-hi bi-l-jilāfa) no es raro en fuentes cronísticas sobre reinados de quienes, como Hišām I, fueron tan sólo emires. No se olvide, en todo caso, que tanto 'Abd Allāh como Sulaymān protagonizaron más tarde rebeliones contra el poder cordobés, tanto de Hišām I como de sus sucesores.

${ }^{90}$ Es llamativo que no se mencione, en todo este relato, la importancia del ejército como pilar del poder omeya. La brevedad con que se cuentan los hechos puede explicar esta omisión, que sin embargo coincide con la mencionada anteriorermente sobre la falta de una presencia sistemática de los militares como miembros del entorno soberano. Sobre el papel del ejército en las sociedades islámicas tempranas, Hugh KENNEDY, The Armies of the Caliphs. Military and Society in the Early Islamic State, London, 2001.

${ }^{91}$ E. LÉVI-PROVENÇAL, Histoire de l'Espagne musulmane, vol. III, Paris, 1953, p. 15. Afirma también Lévi-Provençal (aunque sin citar las fuentes en que se apoya para ello) que el lema grabado en el sello figuraba igualmente en los estandartes que se daban a los generales al salir de expedición y en las inscripciones del țirāz.

${ }^{92}$ Bayān, II, p. 157 y Crónica anónima, p. 29/91. Véase M. FIERRO, Abd al-Rahman III. The First Cordoban Caliph, Oxford 2005. 